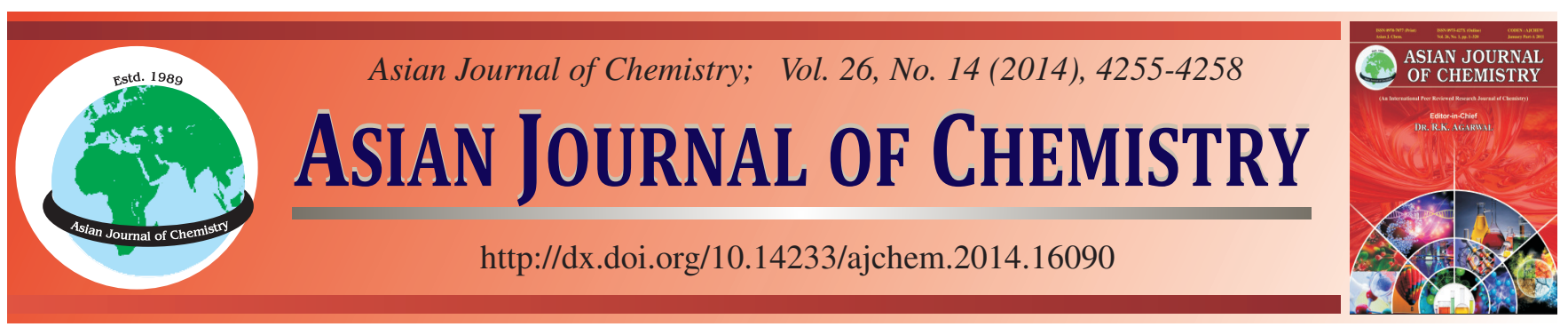

\title{
Synthesis, Characterization and Bioevaluation of (Z)-4-Substituted phenyl- 2-((2-oxoindolin-3-ylidene)aminocyclopent-1-ene carbodithioate) Derivatives from 2-Aminocyclopent-1-ene Carbodithioic Acid
}

\author{
Y.L.N. Murthy ${ }^{1, *}$, Palla Mani ${ }^{1}$, Palla Mahesh ${ }^{1,2}$ and K. Chaguruswamy ${ }^{1}$
}

${ }^{1}$ Department of Organic Chemistry, Andhra University, Visakhapatnam-530 003, India

${ }^{2}$ Jawaharlal Nehru Technological University, Hyderabad-500 085, India

*Corresponding author: Fax: +91 891 2713813; E-mail: murthyyln@ gmail.com

\begin{abstract}
A series of oxoindoline derivatives $\mathbf{6}(\mathbf{a}-\mathbf{e})$ have been synthesized. Treatment of cyclopentanone (1) with carbon disulphide (2) in liq. $\mathrm{NH}_{3}$ yielded 2-amino-cyclopent-1-enecarbodithioic acid (3) which on further treatment with isatin (4) in ethanol under reflux conditions for 2 $\mathrm{h}$ gave (Z)-2-(2-oxoindolin)-aminocyclopentene carbodithioic acid (5). Compound $\mathbf{5}$ was treated with different 1,4 diaryl substituents in THF resulted the formation of the target molecule viz., oxoindoline derivatives $\mathbf{6}(\mathbf{a}-\mathbf{e})$. These compounds were evaluated in vitro antimicrobial activities by agar well dilution method. Oxoindoline derivatives exhibited the broad spectrum of antibacterial activity (compounds $\mathbf{3}, \mathbf{5}$, $\mathbf{6 a}, \mathbf{6 c}, \mathbf{6 e})$ and mild activity (6b and $\mathbf{6 d})$, besides potent antifungal activity.
\end{abstract}

Keywords: Indole, Cyclopentanone, THF, Oxoindoline, Antimicrobial activity.

\section{INTRODUCTION}

Isatin is an endogenous compound, useful for the synthesis of large variety of heterocyclic compounds ${ }^{1}$. The synthetic versatility of isatin has stemmed from the interest in the biological and pharmacological properties of its derivatives. In nature, isatin is found in plants of the genus Isatis, in Calanthe discolor LINDL and also found as a component of the secretion from the parotid gland of Bufo frogs and in humans, as a metabolic adrenaline derivative ${ }^{2}$. Isatin derivatives are reported to show other biological activities like antibacterial $^{3,4,5}$, antifungal ${ }^{6}$, antiviral ${ }^{7}$, anti $\mathrm{HIV}^{8}$, antiprotozoal ${ }^{9}$, muscle relaxant $^{10}$, antitumors ${ }^{11}$, antiallergic ${ }^{12}$, anticonvulsant ${ }^{13,14}$, and antiinflammatory activities ${ }^{15}$.

Prompted by the biological properties of oxoindolines derivatives, it was decided to synthesize various oxoindoline derivatives of isatin with substituted aryl compounds and to screen the synthesized compounds for their antimicrobial activities. The oxoindolin derivatives were synthesized by condensing 2-aminocyclopent-1-ene carbodithioic acid with isatin. All the synthesized target compounds gave satisfactory elemental analysis. IR, ${ }^{1} \mathrm{H} \mathrm{NMR},{ }^{13} \mathrm{C} \mathrm{NMR}$ and mass spectra were in agreement with the assigned structures. All the synthesized compounds were screened for their antibacterial and antifungal activities.

EXPERIMENTAL

All the chemicals used in the present study are of analytical grade and were obtained from local suppliers. Melting points were determined in open capillary tubes and are uncorrected. The purity of the synthesized compounds was routinely checked by TLC on silica gel plates. ${ }^{1} \mathrm{H}$ NMR and ${ }^{13} \mathrm{C}$ NMR spectra were recorded on $400 \mathrm{MHz}$ Fourier-Transform-Nuclear Magnetic Resonance (Bruker Model; Avance-II) Spectrophotometer using TMS as an internal standard (Chemical shifts in $\mathrm{ppm}$ ), IR Spectra were recorded on $\mathrm{KBr}$ disc on Thermo Nicolet (Model: 6700) Spectrophotometer $\left(v_{\max } \mathrm{cm}^{-1}\right)$. Elemental analysis was performed on Carlo Erbo elemental analyzer.

General procedure for the synthesis of 2-aminocyclopent-1-enecarbodithioic acid (3), (Z)-2-((2-oxoindolin) amino cyclopentenecarbodithioic acid (5) and oxoindoline derivatives (6a-6e): An equimolar mixture of cyclopentanone (1) and carbon disulphide (2) with liq. $\mathrm{NH}_{3}$ was taken in 500 mL R.B. Flask and $100 \mathrm{~mL}$ of EtOH was added., The reaction mixture was stirred at $0^{\circ} \mathrm{C}$ for $1 \mathrm{~h}$. The reaction was completed until TLC showed the disappearance of starting material and the solvent was evaporated under reduced pressure, to give yellow solid (3). The crude was washed with ethyl acetate and dried. The synthesized compound was recrystallized with chloroform and petroleum ether. The compound (3) was 
condensed with isatin (4) in $100 \mathrm{~mL}$ of $\mathrm{EtOH}$, the reaction mixture was stirred for $2 \mathrm{~h}$ and refluxed in water bath for $2 \mathrm{~h}$. The reaction mixture was monitored by TLC and after usual workup, the synthesized compound (5) was recrystallized with $\mathrm{CHCl}_{3}$ and petroleum ether, to give (pale brown coloured compound) (Z)-2-(2-oxoindoline aminocyclopentene) carbodithioic acid (5) which is further treated with different 1,4 diaryl substituents in THF drop wise with cooling and shaking. The reaction mixture was allowed to stand at room temperature for $1 \mathrm{~h}$ with occasional shaking and later warmed on a steam bath for $0.5 \mathrm{~h}$. the reaction was monitored by TLC. At the end of reaction the contents (6a-6e) were cooled and product obtained was recrystallized from chloroform and petroleum ether (Scheme-I).

2-Aminocyclopent-1-ene carbodithioicacid (3): The sample was recrystallized using chloroform and petroleum ether. Yield $82 \%$; m.p. $88^{\circ} \mathrm{C}, \mathrm{IR}\left(\mathrm{KBr}, \mathrm{v}_{\max }, \mathrm{cm}^{-1}\right): 1183(\mathrm{C}=\mathrm{S})$, 1265 (C-N), 1314 (C-N), $1468(\mathrm{C}=\mathrm{C}), 3430\left(\mathrm{NH}_{2}\right), 3602(\mathrm{~N}-$ $\mathrm{H}) ;{ }^{1} \mathrm{H}$ NMR $\left(\mathrm{CDCl}_{3}\right)$ ppm: $\delta 1.86(\mathrm{~s}, 1 \mathrm{H}, \mathrm{SH}) \delta 2.02(\mathrm{~S}, 2 \mathrm{H}$, $\mathrm{NH}_{2}$ ), $\delta$ 2.59-2.79 (m, 6H, cyclopentene methylene protons); Anal Calcd for $\mathrm{C}_{6} \mathrm{H}_{9} \mathrm{NS}_{2}$ : Required: C, 45.25, H, 5.70, N, 8.79, S, 40.26; Found: C, 45.30, H, 5.73, N, 8.81, S, 40.23.

(Z)-2-((2-Oxoindolin)aminocyclopent-1-ene)carbodithioic acid (5): The sample was recrystallized using chloroform and petroleum ether. Yield $79 \%$; m.p. $115^{\circ} \mathrm{C}$, IR $(\mathrm{KBr}$, $\left.v_{\max }, \mathrm{cm}^{-1}\right): 1189(\mathrm{C}=\mathrm{S}), 1616(\mathrm{C}=\mathrm{N}), 1726(\mathrm{C}=\mathrm{O}), 3197(\mathrm{NH})$; ${ }^{1} \mathrm{H} \mathrm{NMR}\left(\mathrm{CDCl}_{3}\right)$ ppm: $\delta 1.85(\mathrm{~s}, 1 \mathrm{H},-\mathrm{SH}), \delta 2.76-2.64(\mathrm{~m}$, $6 \mathrm{H}$, cyclopentene methylene protons), $\delta 3.76(\mathrm{NH}), \delta 7.26-$
7.86 (m, 4H, Ar ); Anal Calcd for $\mathrm{C}_{14} \mathrm{H}_{12} \mathrm{~N}_{2} \mathrm{OSS}_{2}$ : Required: $\mathrm{C}$, 58.31; H, 4.19; N, 9.71; S, 22.24; Found: C, 58.28; H, 4.16; N, 9.73; S, 22.24.

(Z)-4-(2-((2-Oxoindolin-3ylidene)aminocyclopent-1ene)carbothioyl)thio) benzoic acid 6(a): The sample was recrystallized using chloroform and petroleum ether. Yield $72 \%$; m.p. $242{ }^{\circ} \mathrm{C}$, IR (KBr, $\left.v_{\max }, \mathrm{cm}^{-1}\right): 1616(\mathrm{C}=\mathrm{O}), 1726$ $(\mathrm{C}=\mathrm{O}$ in $-\mathrm{COOH}), 3030$ (Aromatic C-H), $3197(\mathrm{NH}), 3417$ (O-H); ${ }^{1} \mathrm{H} \mathrm{NMR}\left(\mathrm{CDCl}_{3}\right)$ ppm: $\delta 2.3-2,7$ (m, 6H, cyclopentene methylene protons) $\delta 7.5-7.86(\mathrm{~m}, 4 \mathrm{H} \mathrm{Ar}-\mathrm{H}), \delta 7.9-8.3(\mathrm{~m}$, $4 \mathrm{H}, \mathrm{Ar}-\mathrm{H}), \delta 11.2$ (IsatinN-H) $\delta 13.2(-\mathrm{COOH})$; Anal Calcd for $\mathrm{C}_{21} \mathrm{H}_{16} \mathrm{~N}_{2} \mathrm{O}_{3} \mathrm{~S}_{2}$ : Required: $\mathrm{C}, 61.75 ; \mathrm{H}, 3.95 ; \mathrm{N}, 6.86 ; \mathrm{S}$, 15.70; Found: C, 61.73; H, 3.92; N, 6.89; S, 15.72.

(Z)-Benzyl-2-((2-oxoindolin-3-ylidene)amino)cyclopent-1-ene)carbodithioate 6(b): The sample was recrystallized using chloroform and petroleum ether. Yield $69 \%$; m.p. $128{ }^{\circ} \mathrm{C}, \mathrm{IR}\left(\mathrm{KBr}, \mathrm{v}_{\max }, \mathrm{cm}^{-1}\right): 811$ (-C-S-C-), $1183(\mathrm{C}=\mathrm{S}), 749$, $811(\mathrm{C}-\mathrm{N}), 1616(\mathrm{C}=\mathrm{N}), 1718(\mathrm{C}=\mathrm{O}), 1759(\mathrm{C}=\mathrm{C}) ;{ }^{1} \mathrm{H}$ NMR $\left(\mathrm{CDCl}_{3}\right): \delta$ 1.87-2.79 (m, 6H, cyclopentene methylene protons), $\delta 4.13$ (s, 2H, Bezylic protons), $\delta 7.5-7.81$ (m, $5 \mathrm{H}$, Ar-H), $87.26-7.4$ (m, 4H, Ar-H), $\delta 11.4$ (Isatin N-H); Anal Calcd for $\mathrm{C}_{21} \mathrm{H}_{20} \mathrm{~N}_{2} \mathrm{OS}_{2}$ : Required C,66.64; H,4.79; N,7.40; S, 16.94; Found: C, 66.66; H, 4.83; N, 7.37; S, 16.93

(Z)-4-Aminophenyl-2-((2-oxoindolin-3-ylidene)aminocyclopent-1-ene)carbodithioate 6(c): The sample was recrystallized using chloroform and petroleum ether. Yield 73 \%; m.p. 274-276 ${ }^{\circ} \mathrm{C}$ IR (KBr, $v_{\max }, \mathrm{cm}^{-1)}$ : 1123 (C=S), 1266 (C-N), $1699(\mathrm{C}=\mathrm{O}), 3196(\mathrm{NH}), 3417\left(\mathrm{NH}_{2}\right) ;{ }^{1} \mathrm{H}$ NMR

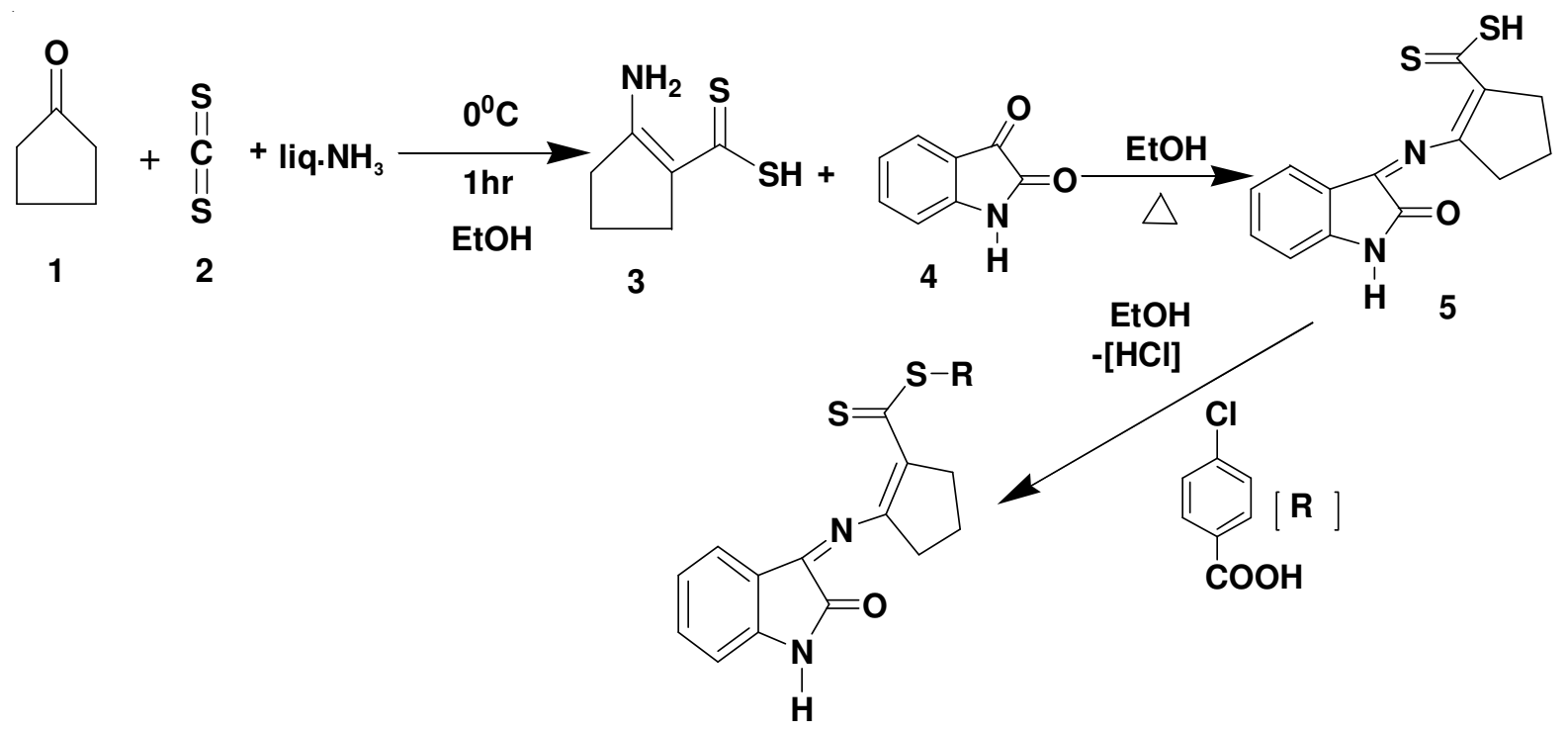

6(a-e)<smiles>[R]=C=Cc1ccc(Cl)cc1</smiles>

$6 a$<smiles>ClCc1ccccc1</smiles>

$6 b$<smiles>Nc1ccc(Cl)cc1</smiles>

6c<smiles>Clc1ccc(Cl)cc1</smiles>

$6 d$<smiles>Nc1cc(Br)cnc1N</smiles>

$6 e$

Scheme-I 
(DMSO- $\left.d_{6}\right): \delta 2.1-2.7$ ( $\mathrm{m}, 6 \mathrm{H}$, cyclopentene methylene protons), $\delta 5.9\left(\mathrm{~S}, 2 \mathrm{H}, \mathrm{Ar}-\mathrm{NH}_{2}\right.$ protons $), \delta$ 6.6-7.0 (m, 4H, Ar- $\left.\mathrm{H}\right), \delta$ 7.26-7.81 (m, 4H Ar-H), $\delta 11.33(\mathrm{~S}, 1 \mathrm{H}$, isatin NH); Anal calcd for $\mathrm{C}_{20} \mathrm{H}_{19} \mathrm{~N}_{3} \mathrm{OS}_{2}$ : Required:. C, 63.30; H, 4.52; N, 11.07; S, 16.90; Found: C, 63.29; H, 4.53, N, 11.05; S, 16.06.

(Z)-4-Chlorophenyl 2-((2-oxoindolin 3-ylidene)aminocyclopent-1-ene carbodithioate) 6(d): The sample was recrystallized using chloroform and petroleum ether. Yield $63 \%$; m.p. $120{ }^{\circ} \mathrm{C}$, IR (KBr, $\left.v_{\max }, \mathrm{cm}^{-1}\right): 1130(\mathrm{C}=\mathrm{S}), 1286$ $(\mathrm{C}-\mathrm{N}) 1620(\mathrm{C}=\mathrm{N}), 1705(\mathrm{C}=\mathrm{O}) ;{ }^{1} \mathrm{H}$ NMR $\left(\mathrm{DMSO}_{6}\right) \mathrm{ppm}: \delta$ 2.1- $2.8(\mathrm{~m}, 6 \mathrm{H}$, cyclopentene methylene protons). $\delta 7.33(\mathrm{~m}$, 4H, Ar-H), $\delta$ 7.5-7.86 (m, 4H, Ar-H), $\delta 13.7$ (s, Isatin N-H); Anal calcd for $\mathrm{C}_{20} \mathrm{H}_{15} \mathrm{~N}_{2} \mathrm{OClS}_{2}$ : Required: C, 60.21; H, 3.79; Cl, 8.89; N, 7.02; S, 16.08; Found: C, 20.24; H, 3.80; Cl, 8.88; N, 7.0; S, 16.06 .

(Z)-5,6-Diaminopyridine-3-yl-2-((2-oxoindolin-3ylidene)aminocyclopent-1-ene)carbodithioate [6(e)]: The sample was recrystallized using chloroform and petroleum ether. Yield $67 \%$; m.p. $247-249^{\circ} \mathrm{C}$; IR( $\left.\mathrm{KBr}, \mathrm{v}_{\max }, \mathrm{cm}^{-1}\right): 1130$ $(\mathrm{C}=\mathrm{S}), 306,1275(\mathrm{C}-\mathrm{N}), 1620,1602,1499(\mathrm{C}=\mathrm{C}), 1724(\mathrm{C}=\mathrm{O})$, $3450,3390(\mathrm{NH}) ;{ }^{1} \mathrm{H}$ NMR (DMSO- $\left.d_{6}\right): \delta 1.87-2.273(\mathrm{~m}, 6 \mathrm{H}$, cyclopentene methylene protons), $\delta$ 6.87-7.67 (d, 2H, Ar-H) $\delta 6.3, \delta 7.8\left(\mathrm{~s}, 2 \mathrm{H},-\mathrm{NH}_{2}\right), \delta 11.4(\mathrm{~s}$, isatin $\mathrm{N}-\mathrm{H})$; Anal, calcd. $\mathrm{C}_{19} \mathrm{H}_{17} \mathrm{~N}_{5} \mathrm{OS}_{2}$ : Required: C, 57.70; H, 4.33; N, 17.71; S, 16.21; Found: C, 57.72; H, 4.35; N, 17.69; S,16.19.

\section{RESULTS AND DISCUSSION}

Treatment of cyclopentanone (1) with carbon disulphide (2) in liq. $\mathrm{NH}_{3}$ at $0{ }^{\circ} \mathrm{C}$ at room temperature for $3 \mathrm{~h}$ yielded in 2-amino-cyclopent-1- enecarbodithioic acid (3), which on further treatment with isatin (4) in ethanol under reflux for $2 \mathrm{~h}$, resulted the formation of (Z)-2-((2-oxoindolin-3-ylidene)amino)cyclopent-1-ene)carbodithioic acid (5) as a pale brown colour crystals, which was confirmed by spectral data. Compound $\mathbf{5}$ on treatment with $p$-chlorobenzoic acid or benzyl chloride or $p$-chloroaniline or 1,4-dichloro benzene separately in THF as a solvent for $1 \mathrm{~h}$ resulted in $(\mathrm{Z})-4-((2-((2-$ oxoindolin3ylidene)aminocyclopent-1-enecarbothioyl)thio)benzoic acid (6a); (Z)-benzyl-2-((2-oxoindolin-3-ylidene)amino)cyclopent1-ene)carbodithioate (6b); (Z)-4-aminophenyl-2-((2-oxoindolin-3-ylidene)aminocyclopent-1-ene)carbodithioate (6c) and (Z)-4-chlorophenyl-2-((2-oxoindolin-3-ylidene)aminocyclopent-1-ene)carbodithioate (6d). Further compound $\mathbf{5}$ when treated with 5-bromo-2,3-diaminopyridine resulted the formation of (Z)-5,6-diaminopyridine-3-yl-2-((2-oxoindolin 3-ylidene) aminocyclopent-1-ene)carbodithioate (6e), respectively. All the synthesized compounds were characterized by the IR, ${ }^{1} \mathrm{H}$ NMR and elemental analysis. IR spectra $\left(\mathrm{cm}^{-1}\right)$ of compounds 5 and 6 showed absorption bands at $3602 \mathrm{~cm}^{-1}(\mathrm{NH}) ; 1283$ $\mathrm{cm}^{-1}(\mathrm{C}-\mathrm{N}) ; 1628 \mathrm{~cm}^{-1}(\mathrm{C}=\mathrm{S}) ; 1402 \mathrm{~cm}^{-1}(\mathrm{C}=\mathrm{C})$ and $1698-1688$ $\mathrm{cm}^{-1}(\mathrm{C}=\mathrm{O})$.

This new procedure provides the first example of three component and catalyst free synthesis of oxoindoline derivatives. The reactions under catalyst free conditions are considerably safe, non-toxic, environmentally friendly and inexpensive. The absence of catalyst for the reaction allows avoiding the use of moisture sensitive and heavy metal lewis acids. This method, based on catalyst free reaction, under solvents, is the most simple and convenient and would be applicable for the synthesis of different types of oxoindoline derivatives. These reactions proceeded very cleanly under mild conditions and no undesirable side reactions were observed. The oxoindoline derivatives $\mathbf{6}(\mathbf{a}-\mathbf{e})$ were synthesized for the first time. The physical constants of synthesized compounds 5 and $\mathbf{6}(\mathbf{a}-\mathbf{e})$ were in arrangement with the structures.

Bioactivity investigations: The newly synthesized compounds were evaluated for their in vitro antimicrobial activities against gram positive, gram negative bacteria and fungi. Among all the synthesized compounds, compound 5, 6a and 6e exhibited potent antagonistic activity against all the tested bacteria used in the study. The highest antibacterial activity against E.coli was exhibited by the compounds $\mathbf{6 c}$ and $\mathbf{6 e}$. The compound $\mathbf{6} \mathbf{b}$ did not form the zone of inhibition, at all the concentrations, used in the study against $P$. aeruginosa. Similarly the compound $\mathbf{6 b}$ doesn't show antagonistic activity against any gram positive bacteria, but inhibited the growth of $S$. aureus at higher concentrations only. The remaining compounds showed moderate antagonistic activity against the test bacteria. compound $\mathbf{5}$ exhibited potent antifungal activitiy against $C$. albicans and $S$. cerevisiae. while the compounds $\mathbf{3}$, $\mathbf{6 a}$ and $\mathbf{6 c}$ showed remarkable activity against fungi.

Antimicrobial activities of substituted oxoindoline derivatives: The antimicrobial activities were determined by agar well diffusion method. The compounds were taken in DMSO at a concentration of 25, 50, 100 and $200 \mu \mathrm{g} / \mathrm{mL}$. Each of these concentrations was tested against gram positive and gram negative bacteria and fungi, respectively. Nutrient agar media and potato dextrose agar media were used for bacteria and fungi. The sterilized media were inoculated with test bacteria and fungi at $45-50{ }^{\circ} \mathrm{C} .6 \mathrm{~mm}$ wells were made on the solidified agar surface; into each of these wells, $0.05 \mathrm{~mL}(50 \mu \mathrm{g})$ of the test compound/reference standard/control was added by using a micropipette. Streptomycin was used as standard reference for bacteria and fluconazole for fungi. DMSO was used as a control (solvent) which did not possess any inhibition zone. The plates were incubated at $37^{\circ} \mathrm{C}$ for $24 \mathrm{~h}$ for bacterial activity and $28^{\circ} \mathrm{C}$ for fungi.

Determination of antimicrobial activities: The assay plates were seeded with gram positive bacteria Bacillus Subtilis (MTCC 441), Staphylococcus aureus (MTCC 3160), Bacillus cereus (MTCC 430) and gram negative bacteria Escherichia coli, (MTCC 443), Pseudomonas aeruginosa (MTCC 424), Proteus vulgaris (MTCC 426) using nutrient agar media and potato dextrose agar media for Saccharomyces cerevisiae (MTCC 170), Candida albicans (MTCC 227). The antimicrobial activities were observed after $24 \mathrm{~h}$ of incubation at $37{ }^{\circ} \mathrm{C}$ for bacteria and at $28^{\circ} \mathrm{C}$ for fungi and the results were expressed as zone of inhibition. The inhibition zone was calculated by measuring the diameter of the zone around the well (in $\mathrm{mm}$ ) including the well diameter. The readings were taken in three different fixed directions in all 3 replicates and the average MIC values were tabulated in Table- 1 .

\section{Conclusion}

Seven new oxoindoline derivatives were synthesized and exhibited a wide range of significant antimicrobial activities, whereas the antibacterial activity of oxoindoline derivatives 


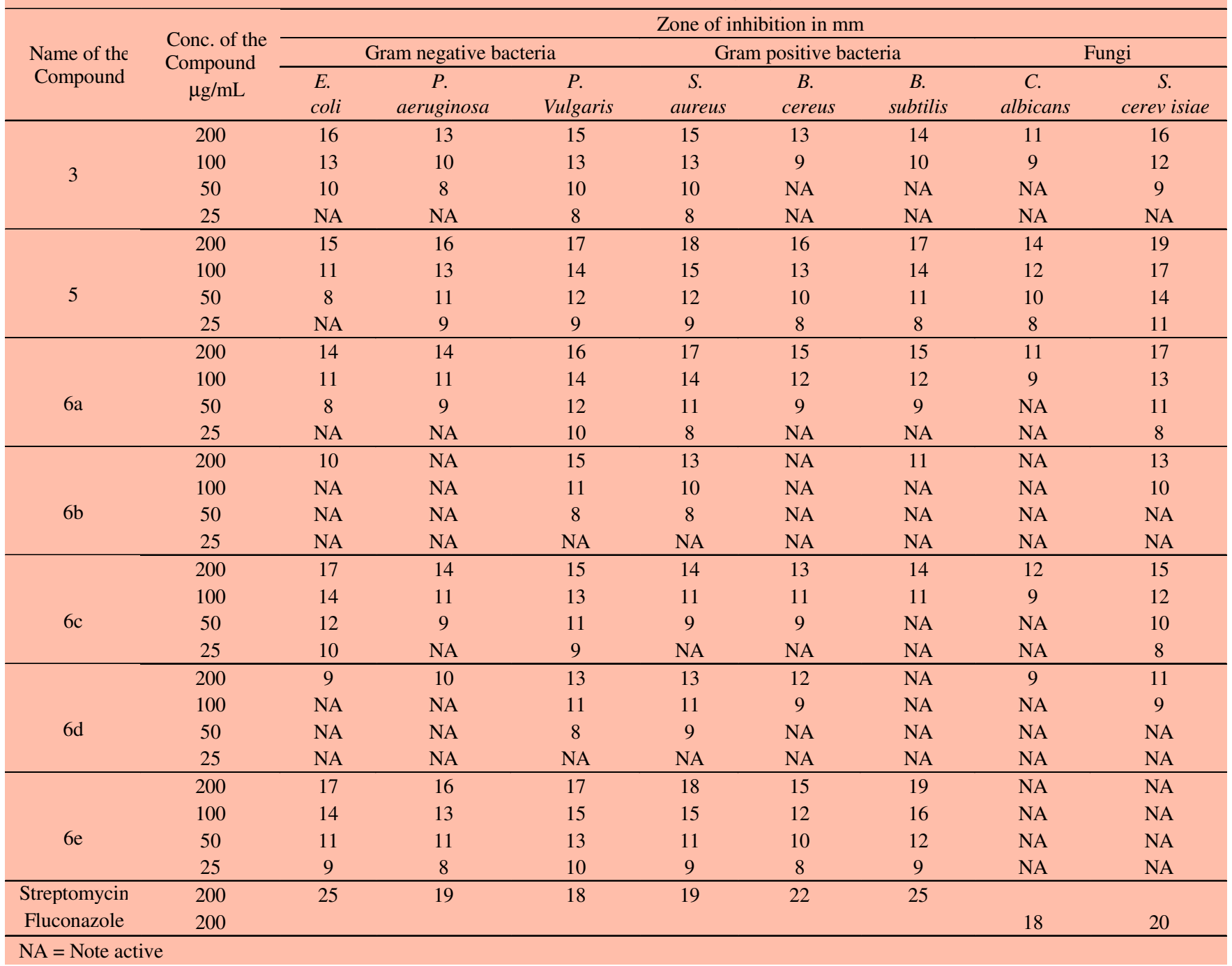

5, $6 \mathbf{a}$ and $\mathbf{6 e}$, showed potent activity. For the antifungal activity, the compound $\mathbf{5}$ showed potent activity than $\mathbf{6 a}, \mathbf{6 c}$. Compounds with carboxylic and amine substituents showed better activity than other substituent.

\section{ACKNOWLEDGEMENTS}

The authors are thankful to Defense Research and Development Organization (DRDO), New Delhi for providing financial assistance. The authors are also grateful to the Committee on strengthening infra-structure for Science \& Technology (COSIST) Labs, Andhra University, Visakhapatnam, India. Further grateful to $\mathrm{M} / \mathrm{s}$ Natco Research Centre, Hyderabad, India for providing high resolution spectral data.

\section{REFERENCES}

1. J.F.M. Silva, S.J. Garden and A.C. Pinto, J. Braz. Chem. Soc., 12, 273 (2001).
2. M. Farghaly, B.F. Abdel-Wahab and E.M. Ahmed, Chem. Heterocycl. Comp., 45, 539 (2009).

3. S.N. Pandeya, Pharm. Turc., 40, 33 (1998).

4. M. Sarangapani, Indian J. Heterocycl. Chem., 3, 257 (1994).

5. R.S. Varma and W.L. Nobles, J. Pharm. Sci., 64, 881 (1975).

6. S.N. Pandeya, D. Sriram, G. Nath and E. De Clercq, Farmaco, 54, 624 (1999).

7. S.P. Singh and S.K. Shukla, Curr. Sci., 52, 766 (1983).

8. S.N. Pandeya, D. Sriram, G. Nath and E. De Clercq, Eur. J. Med. Chem., 35, 249 (2000).

9. S.N. Pandeya, P. Yogeeswari, D. Sriram, E. de Clercq, C. Pannecouque and M. Witvrouw, Chemotherapy, 45, 192 (1999).

10. G. Chen, Y. Wang, X.J. Hao, S.Z. Mu and Q.Y. Sun, Chem. Centr. J., 5, 37 (2011).

11. C. David and T. Marie, Chem. Abstr., 124, 343271 (1996).

12. M. Sarangapani, Indian J. Pharm. Sci., 59, 105 (1997).

13. S.K. Sridhar, S.N. Pandeya and J.P. Stables, Eur. J. Med. Chem., 16, 129 (2002).

14. M. Varma, S.N. Pandeya and K.N. Singh, Acta Pharm., 54, 49 (2004).

15. S.K. Sridhar, Indian Drugs, 38, 174 (2011). 